\title{
Microeconomics
}

Stanisław SZMITKA

\section{INNOVATION \\ AS A DISTINGUISHING FEATURE IN THE MODEL OF FUNCTIONING OF A MODERN MANAGER}

\begin{abstract}
The present article shows how important is the role of innovations in companies, their impact on managing companies as well as how innovations affect companies' competitiveness in the market.

The choice of the topic was influenced, to a large extent, by the author's interests and insights that determine management innovations in contemporary enterprises.

The aim of the article is to show steps must be undertaken to implement management innovations in managerial staff.

The main intention is to describe the level of innovation of managerial staff, measured by implementation of management innovations in modern enterprises. The theoretical part of the article describes managerial staff, i.e. factors shaping the level of innovation, features and tasks of managers.
\end{abstract}

(C) Stanisław Szmitka, 2019.

Szmitka Stanisław, Doctor of economics, Head of the Department of Economics, University of Computer Sciences and Economics, TWP(Society for the Popularization of Culture and Science) Olsztyn, Poland. 
In the empirical part of the work the author presents the results of the research on correlations between the level of innovation in the area of management and the features affecting the environment. There are no significant relationships between characteristics of managerial staff and the intensity of management innovations. These relationships concern age, seniority in managerial positions and education. The statistical analysis also did not demonstrate any significant correlations between company's components such as the type of activity carried out, capital structure, age and size of an enterprise.

The research has shown that implementation of innovations in the area of management and their direct relationship with management styles is an important phenomenon for the functioning of enterprises.

Relationships in the level of innovation as well as the impact of external and internal factors on innovations implemented in enterprises have been studied.

The methods and techniques that can be applied to study the level of innovations are described. The author presents the assessment of innovation in the area of management as a factor influencing the development and financial and non-financial results of an enterprise. Then the author does research concerning identification of the level of innovation in the surveyed enterprises.

An important source of information on management innovations in the surveyed enterprises are direct interviews in enterprises of production, service and trade profiles in the municipality and the town of Ostróda.

\section{Key words:}

Manager, innovation, model, management innovation, organization.

JEL: G3, G32. 


\section{Managers and their tasks}

Nowadays managers in managerial staff are considered the most important people in present-day organizations because they are mainly responsible for the company's success. There is a significant increase in the position and role of managers both in economic and social development.

Different researchers treat the concept of a manager in different categories. The source literature does not provide a precise definition of a manager. Who exactly is a manager and what qualities should they possess to hold this position? What are their duties and what tasks should managers perform?

According to J. Penc, a manager is «a person employed on a managerial position with extensive knowledge and skills necessary to manage people and organizations in conditions of uncertainty and permanent changeability of the environment in which these organizations operate» (Penc, 2000, p. 175).

According to $\mathrm{L}$. $\mathrm{H}$. Haber, a manager is «an employee designated by an entrepreneur who, on their behalf, decides on the use of capital, material and human resources (for example, the use of tools, employment and rewarding employees, distribution of work and evaluation of its performance, etc.) (Haber, 1998, p. 25).

R.W. Griffin thinks that a manager «is someone who is responsible for management process, especially someone who plans and makes decisions, organizes, leads people and controls human, financial, material and informational resources» (Griffin, 2004, p. 7)

A manager is a person, who achieves goals owing to other people because he/she is one of the most important elements of social organization. An organization is an entity consisting of many structures, carrying out various tasks aiming at achieving the set goals. Therefore, if an organization is to function properly and carry out its tasks, its elements must interact with one another.

According to P. F. Drucker, a manager performs two specific tasks that nobody else in an organization does. The first task of a manager is to create a real whole, bigger than the sum of its components, which produces more than the sum of resources invested into it. It requires extraction and giving efficiency to all forces in an organization, first of all human resources, and eliminating all weaknesses. The second task is that every decision and every action of a manager must be harmonized with requirements of immediate and long-term perspective. It must work in two time dimensions: the present and the future (Drucker, 1998, pp. 365-367).

In addition, P. F. Drucker formulated five basic operations that each manager performs: (Penc, 2000, p. 188-189). 
1. A manager sets goals,

2. A manager organizes work and structures,

3. A manager motivates and informs

4. A manager makes evaluation

5. A manager develops people.

\section{The scope of management innovations implemented in the studied enterprises}

This part of the article presents the results of research relating to the degree of innovativeness of the management in a company and the impact of some external and internal factors in the area of management innovations. The research was based on the perception by managerial staff, that is, objective assessments made by managerial staff with variables such as the environment and management innovations. The studies were conducted by means of a direct interview. The prevailing bodies of the research were representatives of top and middle level management staff. Such a choice of respondents was caused by the fact that the subject of research is management innovations, therefore managerial staff have the best knowledge of these issues, including assessment of the environment.

In the research model, the author of the article assumed the following research objectives: identifying the level of management innovations in the studied enterprises, defining the impact of internal factors, i.e. the characteristics of managerial staff as well as the profile of enterprises and external characteristics of the environment on the level of management innovations. The figure below presents the research variables and assumed correlations between them.

Basing on the above figure, it can be stated that innovation of the managerial staff, as a management innovation implementation, is a multidimensional model that includes components such as strategic and structural dimensions, methods as well as practices and programmes of employee motivation and development, creation of inter-organizational ties and information technologies. Each dimension includes newly implemented management solutions in a particular organization.

New significant changes in management areas that have not been applied or implemented so far will be assessed in five dimensions. 
Figure 1. Research model

The research variables and assumed correlations between them

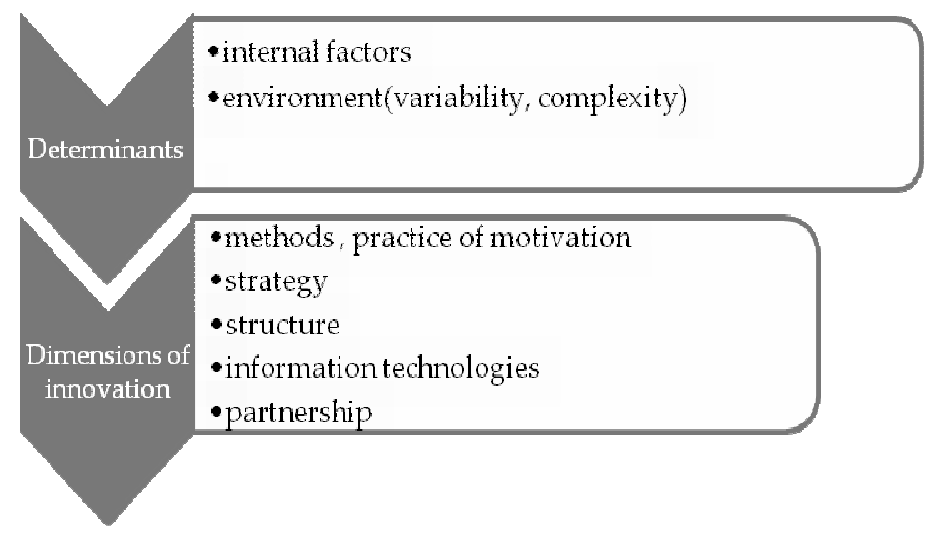

Source: Own elaboration

These significant management changes will be described in the following dimension:

- strategic, i. e. new strategies in the area of competition and development, including other types of innovations, i.e. new services and products, as well as new business models - new markets,

- structural, regarding implementation of new solutions related to organizational structure, thus ensuring flexibility and adaptation to conditions of an organization's functioning, creating new structural forms,

- practices, methods and programmes of motivating related to new practices as well as methods and programmes focused on increasing motivation, skills and competences of employees,

- organizing inter-organizational partnership relationships, the scope of usage, relations in this case with suppliers, customers, recipients, competitors and scientific institutions, creating new forms of cooperation, creating models - open innovation,

- information technologies focusing on knowledge management, which determines the scope and system of changes in acquisition and processing of information.

Changes that constitute management innovations should be introduced on the initiative of higher level management or with its significant participation con- 
cerning the whole organization or its significant areas. Managerial staff or leaders are people who fulfill different functions. Leaders must become citizens of the world who freely move across borders and are able to create connections with other organizations. Leaders must use their abilities to create visions, inspire and enable actions of other people.

Delegation of powers must be used as an incentive for people representing various functions, disciplines and organizations to find some common ground in tasks aimed at improving the entire economy and the standard of living in society, country and in the world (Hesselbein, Goldsmith, Becichard, 1997, pp. 108-109).

The effects of management innovations may extend beyond the functional area, however, not limiting to only one area of operation; they will be different areas, e. g. finance or logistics.

In the research concept, the following determinants of management innovations have been adopted:

- features of managerial staff, especially job seniority, training and age of employees,

- characteristics of company's environment, taking into account hostility, volatility and complexity of an enterprise,

- company profile, where I will take into account such variables as: the length of existence of an enterprise, its size and nature of business, its ownership structure

In the analyzed model, the analysis of environment includes three dimensions: dynamism, i.e. variability, complexity and hostility. A seven-point scale was used here for each aspect.

The research was carried out in enterprises in the municipality and the town of Ostróda in February 2019. The sample was chosen randomly.

The largest percentage of the surveyed enterprises was located in the town of Ostróda. The fewest of the researched companies are in the towns of Morliny and Lubajny. Generally speaking, the sample characteristic reflects the number of enterprises in a particular location.

The division of the structure of the studied enterprises is as follows:

- production $35.5 \%$

- $\quad$ trade $24.3 \%$

- $\quad$ services $24.6 \%$

- $\quad$ mixed $15.6 \%$. 
Table 1

Division of companies by their locations

\begin{tabular}{|c|c|c|}
\hline Location & Number of companies & Percentage (\%) \\
\hline Ostróda & 1 & 20,00 \\
\hline Ostróda & 1 & 20,00 \\
\hline Górka & 1 & 20,00 \\
\hline Morliny & 1 & 20,00 \\
\hline Lubajny & 1 & 20,00 \\
\hline
\end{tabular}

Source: Own elaboration based on the conducted research.

Figure 2

\section{Enterprises by type of activities}

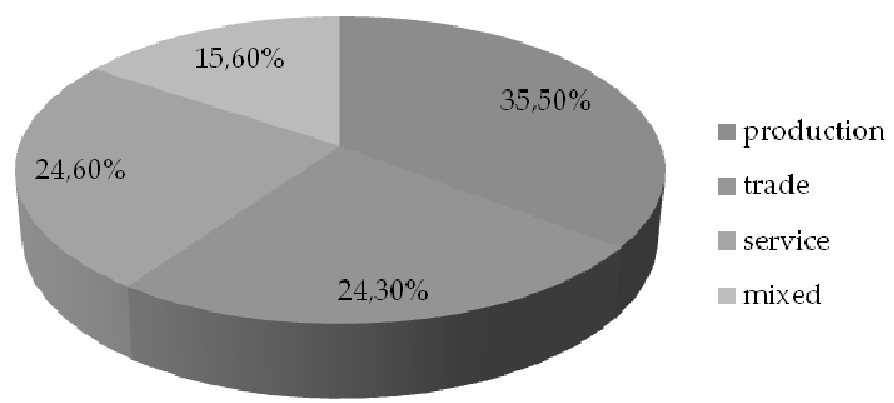

Source: Own elaboration based on the conducted research.

As for ownership structure in the studied enterprises, there are more companies with one hundred percent of national capital, which is $76 \%$, and $6 \%$ of the researched companies are with foreign capital exceeding the level of $51 \%$. The figure below shows the division of enterprises according to their ownership structure

The structure of the studied enterprises in terms of the number of employees is as follows:

- 10-49 employees 6.3\%,

- 50-100 employees $13.6 \%$,

- 101-249 employees $28.2 \%$,

- more than 250 employees $51.8 \%$ 
Figure 3

Detailed ownership structure of the researched enterprises

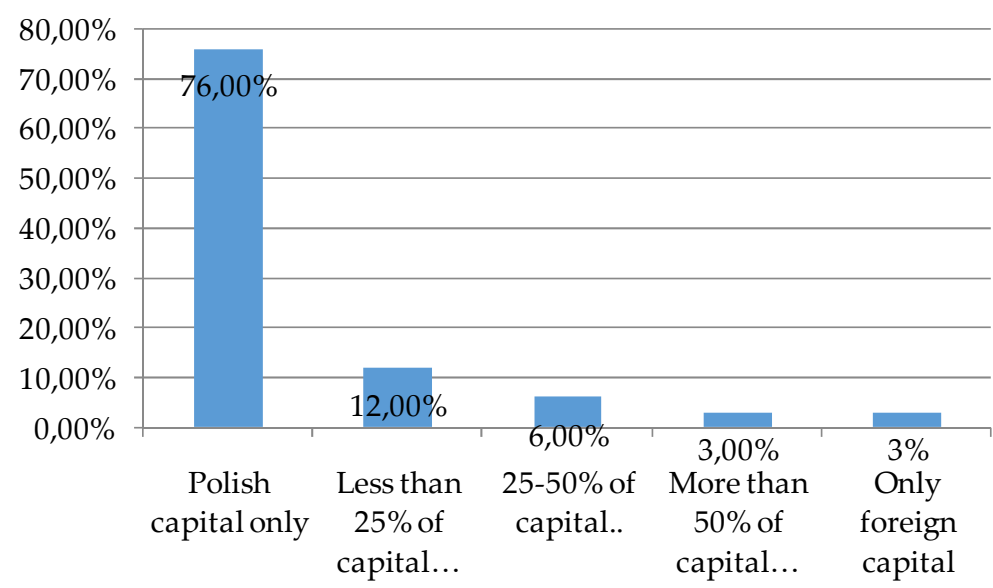

Source: Own elaboration based on the conducted research.

Figure 4

The number of employees in enterprises

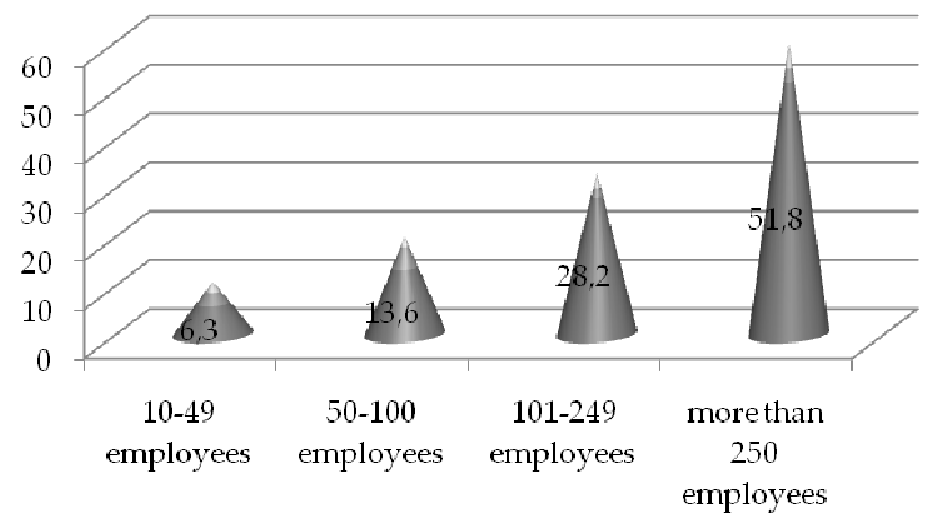

Source: Own elaboration based on the conducted research. 
The majority of enterprises, $64 \%$, have been operating on the market for more than 11 years, while over $23 \%$ of enterprises have been operating on the market from 6 to 10 years. The remaining enterprises have been on the market for no longer than 5 years.

Figure 5

The length of existence on the market in years

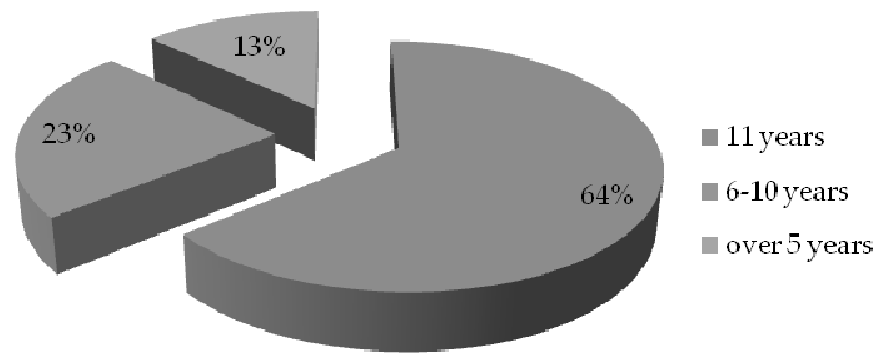

Source: Own elaboration based on the conducted research.

\section{Analysis of correlations between internal conditions}

Internal factors influencing the management innovations in my research include the level of education of managerial staff, age and job seniority in a managerial position.

Among the studied enterprises, we can distinguish enterprises with oneperson board, which accounts for $29 \%$ of total, while the remaining $71 \%$ are enterprises with multi-management board.

In enterprises with one-person management, the majority of managers have higher bachelor or master education. The figure below presents the structure of education of managers in one-person board.

Another factor that characterizes enterprises with one-person management is the age of managerial staff. Nearly $80 \%$, i.e. the vast majority of oneperson management enterprises are management staff aged between 31 and 50 . The job seniority of managers in one-person board companies is 10 years in 
nearly $49 \%$ of the researched companies. In the remaining $43 \%$ of enterprises, job seniority is from 4 to 9 years while seniority shorter than 3 years is in one enterprise only.

Figure 6

The level of education in companies with one-person board

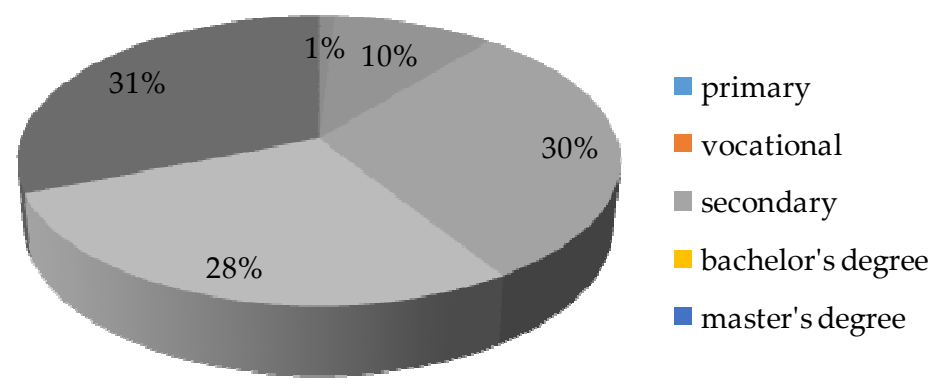

Source: Own elaboration based on the conducted research.

Figure 7

Age structure of managers in enterprises with one-person board

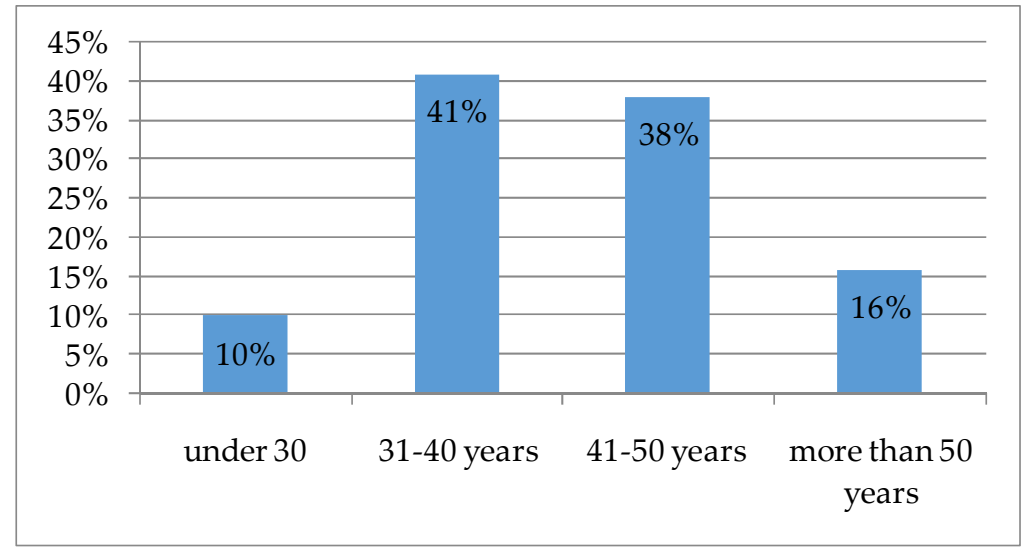

Source: Own elaboration based on the conducted research. 
Another category distinguished in the studied enterprises is multi-person management board, accounting for $71 \%$. All board members in such enterprises have higher education on bachelor or master level in $42.5 \%$ of companies while in $24 \%$ the level of education is varied, however, the majority of managers do have higher bachelor or master education. In the remaining $28 \%$ of enterprises, the level of education is defined as significantly varied; however, still half of managers have higher education. The next criterion is age of board members. In $38 \%$ of enterprises the average age of managers is from 41 to 50 years.

The smallest part $3 \%$ is a group of people who are under 30 years of age. Another $11 \%$ of the analyzed enterprises stated that they did not have such information.

\section{Figure 8}

\section{Age structure of managers in enterprises with multi-person board}

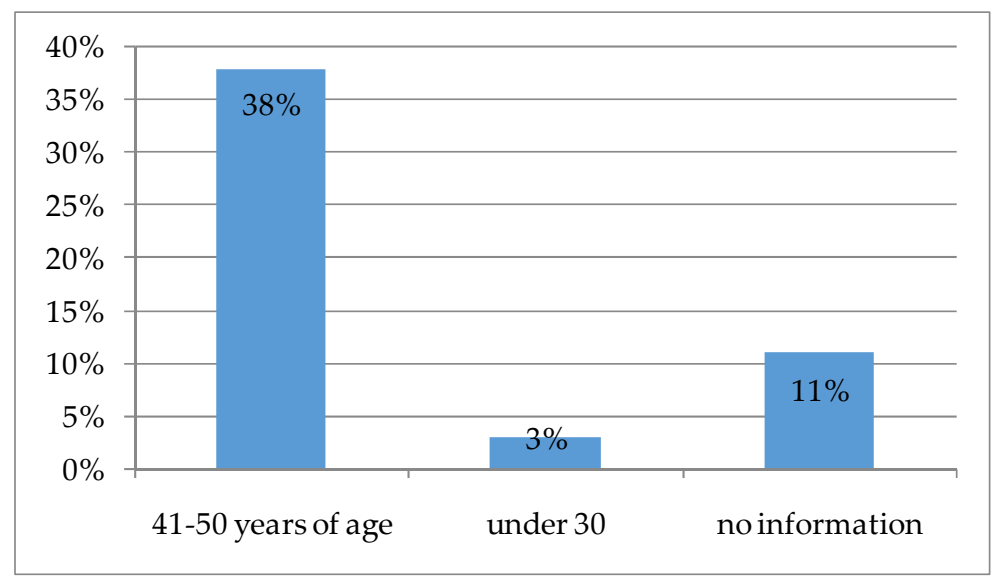

Source: Own elaboration based on the conducted research.

The last characteristic factor of enterprises with multi-person management is job seniority of their members. In $36 \%$ of enterprises, board members have been performing this function for at least 10 years. In $28 \%$ management board's experience varies from 4 to 9 years, while only in $6 \%$ of companies managers' experience is shorter than 3 years. 
Table 2

Length of service in companies with multi-person management board

\begin{tabular}{|l|c|}
\hline \multicolumn{1}{|c|}{ Seniority of board members } & Percentage (\%) \\
\hline board members with a seniority shorter than 3 years & $6 \%$ \\
\hline board members with a seniority of 4 to 9 years & $28 \%$ \\
\hline board members with a seniority of more than 10 years & $36 \%$ \\
\hline members of the top management board- strongly differentiated & $15 \%$ \\
\hline no information & $15 \%$ \\
\hline
\end{tabular}

Source: Own elaboration based on the conducted research.

In order to analyze correlations between determinants and dimensions of innovative management, the Kruskal-Wallis test was used. The Kruskal - Wallis test is one of the most popular alternatives to one-way analysis of ANOVA variance. The Kruskal-Wallis test is carried out when assumptions of the ANOVA variance analysis have been broken or when the nature of our variables does not allow the use of the ANOVA analysis of variance (http://www.naukowiec.org/ wiedza/statystyka/test-kruskalawallisa_754.html, online access dated11.04.2019.

The conducted statistical analysis says that correlations between internal determinants, such as the characteristics of an enterprise profile or the characteristics of managerial staff, and the dimensions of in-innovative management are weak and even do not occur at all. The confirmation of this conclusion is the study of correlations between the type of activity and dimensions of innovative management. No statistically significant correlations were found for these dimensions.

Table 3

Relations between the type of activity and dimensions of innovative management

\begin{tabular}{|l|c|c|c|}
\hline & Chi-square & $\mathrm{df}$ & $\mathrm{p}$ \\
\hline Strategic dimension & 1,514 & 3 & 0,679 \\
\hline Organisational dimension & 0,278 & 3 & 0,964 \\
\hline $\begin{array}{l}\text { Dimension of practices and methods of de- } \\
\text { velopment and motivation of employees }\end{array}$ & 3,016 & 3 & 0,389 \\
\hline Inter-organizational dimension & 0,174 & 3 & 0,982 \\
\hline Information technologies dimension & 0,799 & 3 & 0,85 \\
\hline
\end{tabular}

Source: Own elaboration based on the conducted research. 

of functioning of a modern manager

Other correlations of internal factors such as the characteristics of managers and dimensions of innovative management are also statistically insignificant. This is shown in the table below which presents a correlation coefficient conditioning the dimension of innovation management and job seniority of managerial staff in a multi-person board. The significance of the «p» statistics shows that there is no relationship between the seniority of managerial staff and dimensions of innovation management.

Table 4

Relationships between dimensions of innovative management and job seniority in a multi-person board

\begin{tabular}{|l|c|c|c|}
\hline & Chi-square & df & $p$ \\
\hline Strategic dimension & 7,117 & 4 & 0,129 \\
\hline Organisational dimension & 3,986 & 4 & 0,408 \\
\hline $\begin{array}{l}\text { Dimension of practices and methods of devel- } \\
\text { opment and motivation ofemployees }\end{array}$ & 3,618 & 4 & 0,46 \\
\hline Inter-organizational dimension & 2,729 & 4 & 0,604 \\
\hline Information technologies dimension & 3,221 & 4 & 0,522 \\
\hline
\end{tabular}

Source: Own elaboration based on the conducted research.

There is a small statistical correlation of the studied correlations which proves that characteristics of managers and dimensions of innovation management are irrelevant.

\section{Summary}

This article characterizes the studied enterprises. The research was carried out in the municipality and the town of Ostróda. The research was carried out in companies with the following profiles: trade, service, production and mixed ones. The research used such enterprise data as the amount of owned capital, both national and foreign. The key data that was necessary to conduct the research was the level of education of employees, job seniority in occupied positions as well as the number of employees in individual enterprises. I presented the results of the research which referred to the level of innovation of managerial staff, as well as the impact of some external and internal factors on innovations 
implemented in enterprises. The research was based on objective assessments of managers, using variables such as management innovations and environmental characteristics. The research was carried out by means of a direct interview. These studies were conducted among top and middle level management in the studied enterprises.

The group used for the research was the group of managers because they have the greatest knowledge concerning the assessment of environment. The article described research models to identify the level of innovation in enterprises in which the study was carried out; also, internal factors were identified, that are features of managerial staff as well as the profile of the researched enterprises.

There are also external factors which can be determined by means of measuring the impact of environment characteristics on the level of management innovation. These issues can also be researched; however, such study was not conducted. As a result of the conducted research it was found that the intensity of innovation in management is at a moderate level.

The statistical analysis showed us that correlations between determinants - and these determinants are business or management characteristics and dimensions of innovation management are very weak or do not occur at all. The above conclusions were drawn on the basis of the research on whether the correlations are statistically significant. There is little statistical dependence in the study, which means that characteristics of managers and their impact on dimensions of innovation management are statistically insignificant. Other internal factors that were studied also showed very low and even no statistical relation. Coefficients are less than 5; therefore it is known that correlations will always be insignificant.

\section{Conclusions}

The obtained results of the research explicitly indicate that management innovations are currently a very important phenomenon for functioning of enterprises. We can say that innovations are still very poorly recognized, and hence very poorly researched. This phenomenon enjoys considerable interest of researchers both in the area of management innovations as well as in the organizational part of enterprises.

Currently, there are few studies in this field. We can only say that there exists a huge trend connected with the use of innovative concepts and methods related to modern-day management.

Theoretical studies confirm the fact that innovations are still underestimated. However, we already have a lot of experience in the field of management 
innovations. We are constantly looking for new ways of operating in the field of management innovations, we are also improving methodological workshops in the field of innovations as well as internal and external determinants; and we are still researching the financial and non-financial results achieved by companies in long and short intervals.

The conducted studies were at a level of less than 5 on a seven-level scale, which may indicate the correlations between the features of environment and the level of innovation. The increase in different production methods and techniques used in marketing have a huge impact on this. Marking techniques are necessary to learn customers' needs and to meet these needs.

An interesting result turned out to be research which showed little or no significance between the intensity of management innovations and the characteristics of managerial staff: key features such as age of employees, job seniority and education. Statistical analysis does not prove the existence of statistically significant correlations between the above characteristics and the profile of an enterprise as well as size, age or type of business. Such results may be surprising because research into innovativeness of enterprises usually show the relationship between the size of a company and the level implemented innovations. The above studies present changes and improvements implemented in companies and then called innovations or management innovation. The obtained research results enriched our knowledge of managerial innovation in the field of management.

The following conclusions have been drawn as distinguishing features in the model of functioning of a contemporary manager:

1. A manager who is courageous, not afraid of risk, has knowledge, skills, propriety and is able to motivate the team for effective action is a creator of innovative changes in an enterprise.

2. Knowledge of the market and changing business environment as well as modern communication contribute to understanding of a necessity to introduce innovative changes and overtake competition.

3. Continuous improvement of qualifications and gaining new technological knowledge, learning changes and perceiving them as a factor of development allow meeting the challenges of an innovative enterprise.

4. A manager should possess features of a leader, be an artist and unquestioned authority, and be able to choose employees for whom work is a passion, not just a necessity. 


\section{References}

1. Drucker, F. (1998). Praktyka zarządzania, Warszawa, Nowoczesność Sp. z o.o.

2. Griffin, W. (2004). Podstawy zarządzania organizacjami, Warszawa, Wydawnictwo Naukowe PWN.

3. Haber, H. (1998). Management. Zarys zarządzania małą firmą, Kraków, Wydawnictwo Profesjonalnej Szkoły Biznesu.

4. Hesselbein, F. (1997). Goldsmith M., Becichard R., Lider przyszłości, Wydawnictwo Bizness Press Warszawa.

5. Mroziewski, M. (2005). Style kierowania i zarządzania. Wybrane koncepcje, Warszawa, Centrum Doradztwa i Informacji Difin sp. z o.o.

6. Kast, F.E., Rosenzweig, J.E. (1979). Organization and Management, New York.

7. Penc, J. (2001). Decyzje menedżerskie - o sztuce zarządzania, Warszawa, Wydawnictwo C.H. Beck.

8. Penc, J. (2000). Kreatywne kierowanie. Organizacja i kierownik jutra. Rozwiązywanie problemów kadrowych, Warszawa, Agencja Wydawnicza Placet.

9. Terelak, F. (1999). Psychologia menedżera, Warszawa, Centrum Doradztwa i Informacji Difin sp. z 0.o.

10. Wachowiak, P. (2001). Profesjonalny menedżer. Umiejętność pełnienia ról kierowniczych, Warszawa, Difin Sp. z o.o.

\section{Źródła internetowe}

1. http://www.naukowiec.org/wiedza/statystyka/test-kruskala-wallisa_754.html, dostęp on-line z dnia 22.07.2019 str. 61. 